\title{
Turkish Female Immigrants' Intentions to Participate in Preconception Carrier Screening for Hemoglobinopathies in the Netherlands: An Empirical Study
}

\author{
T. van Elderen ${ }^{\text {b }} \quad$ D. Mutlu ${ }^{c} \quad$ J. Karstanje ${ }^{d} \quad$ J. Passchier ${ }^{\text {e }} \quad$ A. Tibben ${ }^{a}$ \\ H.J. Duivenvoorden ${ }^{a}$ \\ a Department of Medical Psychology and Psychotherapy, Erasmus University Medical Center Rotterdam, \\ Rotterdam, ${ }^{b}$ Department of Clinical and Health Psychology, Leiden University, Leiden, ${ }^{\mathrm{C} P s y c h o t h e r a p e u t i c ~ C e n t e r ~}$ \\ De Viersprong, Rotterdam, ${ }^{\mathrm{d}} \mathrm{Health}$ Center Randweg, Gezondheidscentrum Randweg, Rotterdam, and ${ }^{\mathrm{e}}$ Faculty of \\ Psychology and Education, VU University of Amsterdam, Amsterdam, The Netherlands
}

\section{Key Words}

Hemoglobinopathies • Preconception carrier screening •

The Netherlands • Turkish female immigrants

\section{Abstract}

Background: Preconception carrier screening for hemoglobinopathies (HbPs) is debated in the Netherlands. Objectives: Intentions to participate in preconception carrier screening for $\mathrm{HbPs}$ as well as informed reproductive options were assessed in 109 Turkish female immigrants. Method: Participants completed a structured questionnaire. Results: $83.5 \%$ of 109 Turkish female immigrants intended to participate in preconception carrier screening. Intention to participate was related to the desire to reduce uncertainty about having offspring affected by $\mathrm{HbPs}$, but not with socio-demographic variables, risk-estimation and worrying. If the tests concerning carrier status for $\mathrm{HbPs}$ were confirmative for both partners, $36.3 \%(n=33)$ of the women with the intention of preconception carrier screening would refrain from getting children of their own, including $14.3 \%(n=13)$ opting for adoption, 37.4\% ( $n=34$ ) would decide to become pregnant and to opt for prenatal testing on HbPs. Finally, among
$37.4 \%$ of the women opting for prenatal testing, $30.3 \%(n=$ 10) would terminate an affected pregnancy, $18.2 \%(n=6)$ not and $51.5 \%(n=17)$ could not decide (1 missing value). Conclusion: A large majority of Turkish female immigrants would participate in preconception carrier screening for $\mathrm{HbPs}$.

Copyright $\odot 2010$ S. Karger AG, Basel

\section{Introduction}

Hemoglobinopathies (HbPs) are diseases caused by some malfunction in the hemoglobin molecule and make up a common class of genetic recessive disorders, with about $4.5 \%$ of the world's population carrying a mutation for thalassemias or sickle cell disease [1-3]. Populations in Asia, Africa, the Middle East, Southern Europe, and the Caribbean have the highest prevalence of HbPs or hemoglobin disorders. As a result of global population movements, however, hemoglobin disorders

Prof. T. van Elderen is retired.

\section{KARGER}

Fax +4161306 1234

E-Mail karger@karger.ch

www.karger.com
(C) 2010 S. Karger AG, Basel

$1662-4246 / 10 / 0138-0415 \$ 26.00 / 0$

Accessible online at:

www.karger.com/phg
Hugo Joseph Duivenvoorden, $\mathrm{PhD}$

Department of Medical Psychology and Psychotherapy, Erasmus University Medical Center Rotterdam, Dr. Molewaterplein 50

NL-3015 GE Rotterdam (The Netherlands)

Tel. +31 104087 986, Fax +31 104363 981, E-Mail h.duivenvoorden@erasmusmc.nl 
(thalassemias and sickle cell disorders) are increasingly common in the formerly nonindigenous countries of Northern and Western Europe and in the indigenous countries of Southern Europe, which changing picture has consequences for needs of genetic services [4]. The Netherlands is home to a large number of immigrants ( $\mathrm{n}>2,000,000$ ); between $4 \%$ and $10 \%$ of them may be $\mathrm{HbP}$ carriers [5]. In the Netherlands, about 40 to 60 children are born each year with a severe form of hemoglobinopathy [6]. Without preventive measures, such as preconception and prenatal counseling and possibly the termination of pregnancy, in the next decade the incidence will rise to at least 1,000 severely affected patients [7]. These patients only will be able to survive with intensive medical treatment and likely with a severely impaired quality of life. Additionally, unaware of their carrier status, carrier couples are often totally unexpectedly confronted with an affected child [8]. On the one hand, Streetly [8], for example, emphasizes the need to provide good quality services for people affected by these conditions, mentioning 'genuine informed choice must enable parents to choose to continue with an affected pregnancy in the knowledge that appropriate care is available'. On the other hand, Streetly argues that 'the possibility of prenatal screening for HbPs would mean an end to surprise diagnoses among infants presenting with severe overwhelming infections and splenic crises' [8]. Moreover, prenatal testing enables an informed choice for other preventive measures.

Additionally, it would seem important to offer the atrisk population preconception carrier screening, so that couples can make informed reproductive decisions before pregnancy. The advantage of acquiring this information before pregnancy is that there is less time constraint and a maximum of reproductive options (prenatal diagnosis followed or not followed by pregnancy termination, refraining from having (more) children, adoption, making use of donor sperm/eggs, or preimplantation genetic diagnosis) $[9,10]$.

In Mediterranean countries, the severity of the diseases has led to successful prevention strategies, such as carrier screening for couples before marriage, which has resulted in considerable decline of the incidences of hemoglobin disorders [11-13].

Although prenatal testing is accepted in the Netherlands, preconception carrier screening is still debated. In most western industrialized countries, there has been an ongoing discussion about the ethical aspects of offering carrier screening for autosomal recessive genetic disorders. Although the offer of screening, based on informed consent, might result in preventive management options, it might also increase anxiety in eligible couples. Moreover, the offer of screening might compromise the couple's autonomy. Availability of screening may increase the social pressure to seriously consider and apply for screening. Positive outcomes could result in lowered self-esteem, stigmatization, discrimination and denial of health and life insurance, and employment opportunities $[9,10$, $14,15]$.

There is an additional argument for the danger of victim blaming in immigrant populations, because of the relationship between consanguineous marriages and risk of affected children $[16,17]$. Consanguineous marriage increases the chance that both members of a couple will carry any recessive variant that is being transmitted in their family and that this will manifest in the homozygous state in their children [18]. The risk of an autosomal recessive hereditary disorder increases by $2-3 \%$ in a relationship between cousins [19]. However, in a population where $4-10 \%$ of the people are carriers of HbPs anyway, the additional risk of the consanguineous relationship is relatively lower. Additionally, several expert groups have emphasized the social importance of consanguineous marriages and have warned against the discouragement of consanguineous marriages on medical grounds [18]. Interestingly, measures to prevent the birth of children affected by HbPs, such as premarital screening, preimplantation diagnosis and also termination of pregnancies in the first 100 days of gestation have been taken in many home countries of immigrants with the inclusion of Islamic countries $[12,18]$. In contrast, however, few referrals for genetic counseling for any hereditary or congenital disorder were observed in the Netherlands [20]. The little use of genetic services by immigrants in the Netherlands, compared to the native Dutch population, may be the result of misconceptions among health care professionals about the immigrants' attitude and beliefs about genetics [20-23].

In a Dutch empirical exploration among Turkish female immigrants $(\mathrm{n}=82)$ [21], multivariate regression analyses showed that feelings of uncertainty, risk-estimation and worrying about carrier status for an $\mathrm{HbP}$ were significant determinants of intentions to participate in preconception carrier screening for HbPs. Feelings of uncertainty were included as determinants because in a study of Braithwaite et al. [24] feelings of uncertainty emerged as a strong determinant of intention to participate in predictive genetic testing for hereditary cancer.

In the current study we explored the intentions of Turkish female immigrants, living in the Netherlands, to 
participate in preconception carrier screening for HbPs. Specifically, we aimed to answer the following research questions:

(1a) What is the proportion of Turkish female immigrants planning to become pregnant who would intend to participate in preconception carrier screening for HbPs?

(1b) If the result of the preconception carrier screening appeared to be unfavorable, what proportion of Turkish female immigrants would take the following additional measures to prevent offspring with HbPs: refrain from getting children of their own, including adoption of 1 or more children, prenatal testing and, in case of affected pregnancy, termination of pregnancy?

(2) What is the role, if any, of socio-demographic characteristics with regard to the intention to participate in preconception carrier screening for HbPs?

(3) What is the role of psychological characteristics with regard to the intention to participate in preconception carrier screening for HbPs?

(4) What knowledge do Turkish female immigrants have about HbPs and their hereditary aspects?

The study was approved by the Medical Ethical Review Board of Erasmus University Medical Center, Rotterdam.

\section{Subjects and Methods}

\section{Participants and Procedure}

Ten general practitioners (GPs) in Rotterdam (districts Delfshaven and Feyenoord) each consented to contact 20 Turkish female immigrants aged between 18 and 35 years who were planning to become pregnant. The GPs offered eligible women both oral and written information by a standard protocol. The information concerned the objectives, design and conduct of the scientific study and specifically dealt with the risks of having children with HbPs and general aspects of heredity [25, 26]. Leaflets were available in Dutch and in Turkish. The package also included a prepaid reply letter and an informed consent form. The reply letter was to be returned if participants wished to receive a telephone call from the female Turkish primary investigator (DM) to discuss the matter. A reminder was sent if neither the reply letter nor the informed consent letter was returned and, in almost all cases, followed by a telephone call from the Turkish researcher. As the initial strategy yielded an insufficient number of participants, the same GPs were asked to provide contact details of eligible Turkish female patients. These patients received the same written information together with information intended to clarify potential misconceptions and unrealistic expectations regarding the kind of commitment that the research would entail. After the telephone call, all women but 1 consented to participate in the study. Next, the investigator arranged an interview at these women's home addresses. The interviewer herself was a Turkish female im- migrant, a master student in psychology with a good command of both Turkish and Dutch.

\section{Assessment}

The informants were interviewed with the guidance of a structured questionnaire 'Participation in carrier screening among migrants' (The questionnaire is available at the address of the corresponding author). This structured questionnaire was based on previous focus group interviews and a pilot study [21]. Interviewing took around $1 \mathrm{~h} 45 \mathrm{~min}$. The questions concerned the following issues:

(1a) Intentions to participate in preconception carrier screening for HbPs. The preconception carrier screening was not actually offered. Instead, Turkish female immigrants were asked to imagine what decision they would make if the offer was made.

(1b) Dependent upon the results of genetic screening for HbPs, intentions to take measures to avoid having offspring affected by HbPs (refraining from having offspring of their own including adoption, prenatal testing, termination of pregnancy in the case of finding their offspring were affected by HbPs).

(2) Socio-demographic characteristics: age (divided at the median: $<25$ or $\geq 25$ ); country of birth (Turkey or the Netherlands); residency (living with or without partner; living with or without children); education (low i.e. elementary school or lower vocational education versus medium i.e. secondary and medium vocational education, and high i.e. higher secondary or vocational education; socio-economic status (SES) is represented as the highest educational level in the partnership (for single women their educational level represents their SES); marriage (consanguineous or not); religion (active versus less active); pregnancy (yes or no), and carrier status of an HbP (yes or no) (table 1).

(3) Psychological characteristics: feelings of uncertainty [24, 27] (8 items adapted to preconception carrier screening for HbPs); risk-estimation of being a carrier of an $\mathrm{HbP}$ (1 item); worrying (3 items). For a concise description of these items, see table 2.

(4) Knowledge: previous knowledge about HbPs (1 item) and their hereditary aspects (1 item) (table 1).

\section{Statistical Analyses}

Beforehand, all variables were dichotomized, except educational level, SES and the intention to terminate an affected pregnancy. Counts and percentages were determined for all outcome and predictor variables. The potentialities of predictor variables were examined by the method of logistic regression analysis. Adjusting for confounding was relevant in the relationships between intention to participate in preconception carrier testing and psychological characteristics. Candidate-confounding variables (age, partner, children, SES, pregnancy, consanguinity, being active in religion, and carrier status of an $\mathrm{HbP}$ ) were entered simultaneously in the logistic regression analysis. To provide insight into the impact of confounding variables in the relationships between intention to participate in preconception carrier testing and psychological characteristics, both adjusted and unadjusted results are presented in table 2 . As a performance measure, the odds ratio (OR) is presented, including the $95 \%$ confidence interval (95\% CI). If the $95 \%$ CI did not include the value of odds ratio $=1.00$, then the determinant was considered to be significant at the 0.05 level (two-tailed). All statistical testing took place at a level of significance of 0.05 (two-tailed). 
Table 1. Relationships between intention to participate in preconception carrier screening for HbPs and socio-demographic characteristics $(\mathrm{n}=109)$

\begin{tabular}{|c|c|c|c|c|c|}
\hline & \multicolumn{3}{|c|}{ Intention to participate in preconception carrier screening } & Odds ratio & $95 \%$ CI \\
\hline$\geq 25$ & $50(45.9)$ & $42(46.2)$ & $8(44.4)$ & 1.07 & $0.39-2.96$ \\
\hline$<25$ & $59(54.1)$ & $49(53.8)$ & $10(55.6)$ & & \\
\hline \multicolumn{6}{|l|}{ Country of birth } \\
\hline \multicolumn{6}{|l|}{ Residency } \\
\hline With partner & $72(66.1)$ & $61(67.0)$ & $11(61.1)$ & 1.29 & $0.46-3.67$ \\
\hline Without partner & $37(33.9)$ & $30(33.0)$ & $7(38.9)$ & & \\
\hline With children & $54(49.5)$ & $44(48.4)$ & $10(55.6)$ & 0.75 & $0.27-2.07$ \\
\hline Without children & $55(50.5)$ & $47(51.6)$ & $8(44.4)$ & & \\
\hline \multicolumn{6}{|l|}{ Education } \\
\hline Low & $17(15.6)$ & $12(13.2)$ & $5(27.8)$ & & \\
\hline Middle & $58(53.2)$ & $49(53.8)$ & $9(50.0)$ & 2.27 & $0.64-8.01$ \\
\hline High & $34(31.2)$ & $30(33.0)$ & $4(22.2)$ & 3.13 & $0.72-13.67$ \\
\hline \multicolumn{6}{|l|}{ Consanguinity } \\
\hline Yes & $25(22.9)$ & $23(25.3)$ & $2(11.1)$ & 2.71 & $0.58-12.67$ \\
\hline No & $84(77.1)$ & $68(74.7)$ & $16(88.9)$ & & \\
\hline \multicolumn{6}{|l|}{ Religion } \\
\hline Active & $62(56.9)$ & $49(53.8)$ & $13(72.2)$ & 0.45 & $0.15-1.36$ \\
\hline Nonactive & $47(43.1)$ & $42(46.2)$ & $5(27.8)$ & & \\
\hline \multicolumn{6}{|l|}{ Pregnancy } \\
\hline Yes & $8(7.3)$ & $8(8.8)$ & $0(0.0)$ & 3.77 & $0.21-68.20$ \\
\hline
\end{tabular}

${ }^{a}$ Column percentages. ${ }^{b}$ Age was divided into two categories at the median. ${ }^{c}$ SES represents the highest education level in the partnership, for single women their educational level represents their SES.

\section{Results}

\section{Socio-Demographic Characteristics}

In 2004 and 2005, 109 Turkish female immigrants in the Netherlands, aged between $18-36$ years $(\overline{\mathrm{x}}=25.61$, $\mathrm{s}=5.37$ ), patients of 10 GPs in Rotterdam and planning to become pregnant, consented to participate in the study. Eight pregnant female immigrants were included as well. All women's parents and grandparents and their partners' parents and grandparents had been born in Turkey. Four females identified as carriers of an $\mathrm{HbP}$ were included (1 female with sickle cell disease, 3 females with an unknown $\mathrm{HbP}) ; 2$ of them with family members also identified as carriers of an HbP. In addition, 2 family members of females not identified as carriers were carriers of an HbP. One person had a family member with an $\mathrm{HbP}$ and was included as well. Due to the very small numbers, these variables were not included in (analyses of) table 1 . Table 1 presents the socio-demographic data both in frequencies and percentages.

\section{Psychological Characteristics}

Results concerning 'Feelings of uncertainty', 'Riskestimation' and 'Worrying' are presented in table 2. 
Table 2. Relationships between intention to participate in preconception carrier screening for HbPs and psychological characteristics

\begin{tabular}{|c|c|c|c|c|c|c|c|}
\hline & \multirow{2}{*}{$\begin{array}{l}\mathrm{n}(\%)^{\mathrm{a}} \\
\text { (total } \\
\mathrm{n}=109)\end{array}$} & \multicolumn{2}{|c|}{$\begin{array}{l}\text { Intention to participate in preconception carrier } \\
\text { screening }\end{array}$} & \multirow[t]{2}{*}{$\begin{array}{l}\text { Odds } \\
\text { ratio }^{\mathrm{b}}\end{array}$} & \multirow[t]{2}{*}{$95 \%$ CI } & \multirow[t]{2}{*}{$\begin{array}{l}\text { Odds } \\
\text { ratio }^{c}\end{array}$} & \multirow[t]{2}{*}{$95 \%$ CI } \\
\hline & & yes $(n=91), n(\%)^{a}$ & no $(\mathrm{n}=18), \mathrm{n}(\%)^{\mathrm{a}}$ & & & & \\
\hline $\begin{array}{l}\text { I would rather be certain about being } \\
\text { carrier or not than to live with uncertainty }\end{array}$ & $89(81.7)$ & $78(85.7)$ & $11(61.1)$ & 3.82 & $1.25-11.64$ & 4.93 & $1.37-17.73$ \\
\hline $\begin{array}{l}\text { If I didn't have a genetic test I would always } \\
\text { be wondering whether I was going to get } \\
\text { children with an HbP }\end{array}$ & $77(70.6)$ & $70(76.9)$ & $7(38.9)$ & 5.24 & $1.80-15.21$ & 6.37 & $1.87-21.67$ \\
\hline $\begin{array}{l}\text { The relief I would get from a good result } \\
\text { makes it worth the risk that the result is bad }\end{array}$ & $94(86.2)$ & $83(91.0)$ & $11(61.1)$ & 6.60 & $2.00-21.78$ & 6.53 & $1.61-26.42$ \\
\hline $\begin{array}{l}\text { Knowing the result of a genetic test would } \\
\text { mean I felt more in control }\end{array}$ & $85(78.0)$ & $74(81.3)$ & $11(61.1)$ & 2.77 & $0.94-8.19$ & 3.15 & $0.89-11.12$ \\
\hline $\begin{array}{l}\text { It is better to know that I can get children } \\
\text { with an HbP, even if I can't prevent it }\end{array}$ & $90(82.6)$ & $80(87.9)$ & $10(55.6)$ & 5.82 & $1.89-17.89$ & 5.95 & $1.50-23.60$ \\
\hline
\end{tabular}

\section{Risk-estimation}

\begin{tabular}{l}
$\begin{array}{l}\text { What is the probability that you are carrier } \\
\text { of an HbP? (high) }\end{array}$ \\
\hline
\end{tabular}

Worrying

\begin{tabular}{|c|c|c|c|c|c|c|c|}
\hline $\begin{array}{l}\text { Are you worrying right now about being } \\
\text { carrier of an HbP? (yes) }\end{array}$ & $27(24.8)$ & $25(27.5)$ & $2(11.1)$ & 3.03 & $0.65-14.14$ & 3.63 & $0.71-18.70$ \\
\hline $\begin{array}{l}\text { Are you worrying right now about getting } \\
\text { children with an HbP? (yes) }\end{array}$ & $27(24.8)$ & $23(25.3)$ & $4(22.2)$ & 1.18 & $0.35-3.96$ & 1.08 & $0.30-3.93$ \\
\hline $\begin{array}{l}\text { Are you worrying right now about } \\
\text { undergoing a carrier test for an HbP? (yes) }\end{array}$ & $19(17.4)$ & $16(17.6)$ & $3(16.7)$ & 1.07 & $0.28-4.12$ & 1.10 & $0.26-4.60$ \\
\hline
\end{tabular}

${ }^{a}$ Column percentages. ${ }^{b}$ Unadjusted odds ratio. ${ }^{c}$ Odds ratio adjusted for age, partner, children, SES, pregnancy, consanguinity, being active in religion, and carrier status of an HbP.

Intentions to Participate in Preconception Carrier

Screening and to Take Additional Preventive

Measures in Case of Assumed Carrier Status for HbPs

for Both Parents

Of the 109 women, 91 (83.5\%) reported that they intended to participate in preconception carrier screening, if it was offered. Table 3 shows that, if the screening confirmed carrier status for HbPs for both partners, 36.3\% $(\mathrm{n}=33)$ of those 91 women would refrain from giving birth. Secondly, among these 33 females, $14.3 \%(n=13)$ would opt for adoption. Thirdly, 37.4\% ( $\mathrm{n}=34)$ of these 91 females would try to become pregnant and then have prenatal testing, if offered. This means that $62.6 \%(n=57)$ of these 91 women would have the intention to participate in preconception screening and not in antenatal testing. Finally, $30.3 \%(\mathrm{n}=10)$ of the 33 women who would have the intention to participate in prenatal testing would prematurely terminate a pregnancy affected by severe forms of HbPs, while $18.2 \%$ of the 33 women $(n=6)$ would not prematurely terminate an affected pregnancy, and $51.5 \%$ 
Table 3. Intention to take additional preventive measures in case of confirmed carrier status for HbPs for both partners

\begin{tabular}{lrr}
\hline & $\%(\mathrm{n})$ & $95 \%$ CI \\
\hline $\begin{array}{l}\text { Decision to refrain from having own offspring }(\mathrm{n}=91) \\
\text { Adoption }(\mathrm{n}=91) \text { : a subgroup of females belonging to the group of }\end{array}$ & $36.3(33)$ & $26.4-46.2$ \\
$\quad 33$ females refraining from having own offspring & $14.3(13)$ & $7.1-21.5$ \\
Prenatal testing $(\mathrm{n}=91)$ & $37.4(34)$ & $27.5-47.3$ \\
Termination of affected pregnancy ( $\mathrm{n}=33$, one missing value) & $30.3(10)$ & $14.6-46.0$ \\
$\quad$ Yes & $18.2(6)$ & $5.0-31.4$ \\
$\quad$ No & $51.5(17)$ & $34.4-68.9$ \\
Don't know & \\
\hline
\end{tabular}

( $\mathrm{n}=17)$ did not know what they would decide. The data for this item was missing for 1 of the 34 Turkish female immigrants.

If both parents turned out to be a carrier, 29 of $91 \mathrm{fe}-$ males with the intention to participate in preconception carrier screening answered 'no' on all 4 preventive measures. The intention to take one or more preventive measures versus no preventive measure at all was neither statistically significant related to 'having children or not' $(\mathrm{p}=0.60)$, nor to 'being active in religion or not' $(\mathrm{p}=0.20)$.

With respect to the intention to take specific preventive measures in case of carriership in both spouses, no significant differences were found between Turkish female immigrants with and without the intention to participate in preconception carrier screening. However, there was a marginal statistical significance $\left(\chi^{2}=2.87\right.$; $p<0.07)$ for intention to participate in prenatal testing under these circumstances, with a larger proportion of women in the affirmative group with respect to preconception carrier screening.

\section{Relationships between Intention to Participate} in Preconception Carrier Screening for HbPs and Socio-Demographic Characteristics

Logistic regression analyses revealed that none of the socio-demographic characteristics had a significant relationship with regard to intentions to participate in preconception carrier screening for HbPs (table 1).

\section{Relationships between the Intention to Participate \\ in Preconception Carrier Screening for HbPs and \\ Psychological Characteristics}

Logistic regression analyses, both adjusted and unadjusted for confounding socio-demographic variables, suggested that all uncertainty items except 2 of them
('I think it is tempting fate to ask questions about the future health of our children.' and 'Knowing the result of a genetic test would mean I felt more in control.'), proved to have statistically significant relationships with intention to participate in preconception carrier screening for HbPs. The wish to reduce uncertainty therefore went along with intention to participate in carrier screening. However, risk-estimation of being a carrier of an $\mathrm{HbP}$ and worrying about carrier status, having affected children and undergoing preconception carrier testing could not be considered of significant relevance to the intention to participate in preconception carrier screening.

\section{Knowledge about HbPs and Their Hereditary \\ Characteristics}

Seventy-seven women in our study (70.5\%) had never heard about HbPs, 18 (16.5\%) knew about HbPs but did not know they are hereditary and only 14 (13.0\%) knew about HbPs as hereditary diseases. Knowledge about $\mathrm{HbPs}$ and their hereditary characteristics did not have a significant relationship with the intention to participate in preconception carrier screening for HbPs (table 1).

\section{Discussion}

The large majority of the Turkish women who participated in this study would have the intention to participate in preconception carrier screening, if it was offered to them. It would seem, therefore, that the policy of offering this possibility is highly acceptable among female Turkish immigrants in the Netherlands. In agreement with these findings, many parents from immigrant populations in the UK were positive about preventive measures for HbPs. Interestingly, surveyed people even complained 
that all kinds of measures would have a higher priority if HbPs were most prevalent in Caucasian populations [22]. In Turkey, a large majority of a subset of the population ( $\mathrm{n}=179$ ) was also willing to undergo genetic testing to determine cancer risk and to take preventive measures for themselves and their offspring [28]. Despite this acceptability, however, there is a low uptake of genetic services among immigrants in the Netherlands [20] and other countries [22]. The low uptake of genetic services for HbPs among immigrants has been attributed to a variety of factors. The most important of these are lack of knowledge among general practitioners about these conditions and misconceptions about norms and values among immigrants [22]. For example, health care providers assumed that immigrants would refuse to terminate pregnancies and did not refer them. Hence, many parents were left with no choice. Ahmad and Atkin [23] concluded that cultural myths could undermine accepted good medical practice.

If the screening concerning carrier status for $\mathrm{HbPs}$ was confirmative for both parents, almost two-thirds of the informants concerned would still have their own offspring. A small minority would opt for adoption. Onethird of the informants would opt for prenatal testing of HbPs and one-third of the informants opting for prenatal testing would terminate a pregnancy affected by HbPs. From earlier research on an immigrant population of comparable age living in the Netherlands, it appeared that $68 \%$ of Hindustanis, $42 \%$ of Surinamese Afro-Americans and only $16 \%$ of Moroccans would decide to terminate an affected pregnancy [29]. The apparently limited wish for selective abortion expressed by Moroccans proved to be in contrast, however, with the high number of illegal abortions reported among married women in Morocco (39\%) [29].

It appears that the degree of acceptability of prenatal testing and termination of affected pregnancies among Turkish female immigrants in our study is relatively low. Data in our study, however, showed that the majority were hardly familiar with HbPs, let alone the clinical implications of the diseases. Although the participants had been informed about HbPs shortly before the interview, they may not have had the opportunity to sufficiently assimilate the knowledge and share it with other people of importance to them.

Socio-demographic characteristics showed no significant relationships with regard to intentions to participate in preconception carrier screening. Finding no difference between females with and without children regarding the intention to participate is in contrast to the study of Lake-

Preconception Carrier Screening for Hemoglobinopathies man et al. [10] in which having children turned out to be a declining factor in carrier screening for cystic fibrosis (CF) and/or HbPs. Eight pregnant females were included as well: pregnant female immigrants were considered as capable as nonpregnant females to imagine what decision they would make when the offer was made. All pregnant females intended to participate in preconception carrier screening when the offer was made. Due to the small number of pregnant females, pregnancy was not found to have a statistically significant relationship with intention to participate (table 1). Due to the very small number of female carriers (4), carrier status of an $\mathrm{HbP}$ was not included in (analyses of) table 1.

It seems that for most participants in the present study, the wish to reduce uncertainty induced the intention to participate in preconception carrier screening. In contrast, risk-estimation of being a carrier of an $\mathrm{HbP}$ and worrying about carrier status, having affected children and undergoing preconception carrier screening were not found to be relevant in this respect. More than half of the Turkish female immigrants thought it very unlikely or unlikely to be a carrier of an HbP. The vast majority did not report anxiety about carrier status, and a similar proportion claimed not to worry about having children affected by HbPs. Although our results, however, showed no significant relationship between intention to participate in preconception carrier screening and risk-estimation, 51 out of 91 (56\%) Turkish female immigrants who had the intention to participate in carrier screening estimated their risk of carrier status unlikely or very unlikely, while 14 out of 18 (78\%) females without intention to participate estimated this risk unlikely or very unlikely. In the same line of reasoning, the vast majority did neither report anxiety about carrier status, nor about having children affected by HbPs. Again, although our results showed no significant relationship between the intention to participate in preconception carrier screening and worrying about carrier status, among females with the intention to participate in preconception carrier screening $27.5 \%$ were worrying about carrier status, while only $11.1 \%$ of females without intention to participate were worrying about carrier status. Research with a larger population of females might show that women, who perceive a high risk of carrier status and worry more about carrier status, are more willing to participate in preconception carrier screening.

Additionally, we expect that with increased knowledge about the clinical implications of HbPs this population will have a more rational risk-estimation and will worry more about carrier status. As a consequence, more females might have the intention to participate in pre- 
conception carrier screening. More research with a larger population is needed, however, on the relevance of the interaction between risk-estimation, knowledge and worrying about the decision to participate in preconception carrier screening.

\section{Strengths and Limitations of the Study}

An advantage of this study was that a Turkish female immigrant interviewer from the same city of Rotterdam, with a good command of both Turkish and Dutch, informed and interviewed the participants in our study. In addition, our study was preceded by focus group interviews and pilot-studies concerning knowledge of $\mathrm{HbPs}$, attitudes and intentions for preconception carrier screening for HbPs and other genetic services [20,21]. Therefore, we knew that Turkish female immigrants were hardly familiar with HbPs and the clinical and hereditary implications. As a consequence, the Turkish female immigrants in our study were offered extensive information about these subjects shortly before they were asked to participate. A limitation of this study was that we could not actually offer preconception carrier screening. There could be a discrepancy between intentions and actual behavior, as explained in the Theory of Planned Behavior [30]. A second limitation was that the number of females not intending to participate in preconception carrier screening was too small to draw strong conclusions. Finally, the study was conducted in 1 city; we need to expand our study nationwide to increase the generalizability.

\section{Conclusions}

The acceptability of preconception carrier screening among the studied population of Turkish female immigrants is high. However, it appears that the degree of acceptability of prenatal testing and termination of affected pregnancies among the studied Turkish females is relatively low. Taken into account that the participants in our study were hardly familiar with the hereditary and clinical implications of HbPs, more health education and genetic counseling about $\mathrm{HbPs}$ is needed to reach sound informed decision-making. The first steps towards better education have already been made. For example, in 2005 the National Genetic Information Centre (Stichting Erfocentrum) in cooperation with the Municipal Mental Health Center of Amsterdam set up a series of health education meetings about hemoglobin disorders [31]. Visitors could watch stage plays in several languages (Turkish, Moroccan, Papiamento, Sranan Tongo, Dutch and English) and attend panel discussions featuring experts on these disorders [31]. Subsequently, in 2006, the National Genetic Information Centre in cooperation with the Erasmus Medical Center, Rotterdam developed 'Pregnancy and Risk' (Zwangerwijzer), a self-report questionnaire aimed at providing information about pregnancy risks [32]. Part of the questionnaire deals with the risk of hereditary diseases, including hemoglobin disorders.

\section{References}

1 Alswaidi FM, O’Brien SJ: Premarital screening programmes for haemoglobinopathies, HIV and hepatitis viruses: review and factors affecting their success. J Med Screen 2009; 16:22-28.

2 Patrinos GP, Grosveld FG: Pharmacogenomics and therapeutics of hemoglobinopathies. Hemoglobin 2008;32:229-236.

3 Watson J: DNA. The Secret of Life. London, William Heinemann, 2003.

-4 Modell B, Darlison M, Birgens H, Cario H, Faustino P, Giordano PC, Gulbis B, Hopmeier P, Lena-Russo D, Romao L, Theodorsson E: Epidemiology of haemoglobin disorders in Europe: an overview. Scand J Clin Lab Invest 2007;67:39-70.
5 Giordano PC, Harteveld CL: Prevention of hereditary hemoglobinopathies in the Netherlands. Ned Tijdschr Geneeskd 2006;150: 2137-2141 [Dutch].

-6 Heijboer H, van den Tweel XW, Peters M, Knuist M, Prins J, Heymans HS: One year of neonatal screening for sickle-cell disease in Emma Children's Hospital/Academic Medical Center Amsterdam. Ned Tijdschr Geneeskd 2001;145:1795-1799 [Dutch].

7 Giordano PC: Hemoglobinopathieën in Nederland. Diagnostiek, epidemiologie en preventie (Hemoglobinopathies in the Netherlands. Diagnostics, epidemiology and prevention). Ridderkerk, Ridderprint, 1999 [Dutch].

8 Streetly A: in Kmietowicz Z (ed): Sickle cell screening makes genetic counselling everybody's business. BMJ 2006;332:570. $\checkmark 9$ Lakeman P, Plass AM, Henneman L, Bezemer PD, Cornel MC, Ten Kate LP: Threemonth follow-up of Western and nonWestern participants in a study on preconceptional ancestry-based carrier couple screening for cystic fibrosis and hemoglobinopathies in the Netherlands. Genet Med 2008;10:820-830.

-10 Lakeman P, Plass AM, Henneman L, Bezemer PD, Cornel MC, Ten Kate LP: Preconceptional ancestry-based carrier couple screening for cystic fibrosis and haemoglobinopathies: what determines the intention to participate or not and actual participation? Eur J Hum Genet 2009; 17:999-1009.

11 Modell B, Kuliev AM: Services for thalassaemia as a model for cost-benefit analysis of genetic services. J Inherit Metab Dis 1991;14: 640-651. 
12 Angastiniotis M: Worldwide status of thalassaemia-impact and potential approaches (abstract book). The 8th international conference on thalassaemia and the hemoglobinopathies and the 10th Thalassaemia parent and Thalassaemics International Federation Conference (TIF). Athens, ERA, October 2001, pp 14-15.

13 Bain BJ: Neonatal/newborn haemoglobinopathy screening in Europe and Africa. J Clin Pathol 2009;62:53-56.

14 Markel H: The stigma of disease: implications of genetic screening. Am J Med 1992; 93:209-215.

15 Health Council of the Netherlands: Preconception care: a good beginning. The Hague: Health Council of the Netherlands, 2007; publication no. 2007/19.

16 Ahmad WI, Bradby H: Locating ethnicity and health: exploring concepts and contexts. Sociol Health Ill 2007;29:795-810.

-17 Sirdah M, BiltoYY, El Jabour S, Najjar KH: Screening secondary school students in the Gaza strip for beta-thalassaemia trait. Clin Lab Haematol 1998;20:279-283.

18 Modell B, Darr A: Genetic counselling and customary consanguineous marriage. Nat Rev 2002;3:225-229.

19 Jaber L, Halpern GJ, Shohat M: The impact of consanguinity worldwide. Community Genet 1998;1:12-17.
20 Talan D, van Elderen T, Hoogenboom J: Ongelijk verdeeld. Migranten vragen minder én ander klinisch genetisch advies. Medisch Contact 2004;59:1828-1829.

21 Mutlu D: What motivation do Turkish women have to participate in preconception carrier testing for HbPs?; thesis, Leiden University, Leiden, www.bibliotheek.leidenuniv.nl, 2005 [Dutch].

22 Atkin K, Ahmad WI, Anionwu EN: Screening and counselling for sickle cell disorders and thalassaemia: the experience of parents and health professionals. Soc Sci Med 1998; 47:1639-1651.

23 Ahmad WI, Atkin K: Ethnicity and caring for a disabled child: the case of children with sickle cell or thalassaemia. Br J Soc Work 1996;26:755-775.

24 Braithwaite D, Sutton S, Steggles N: Intention to participate in predictive genetic testing for hereditary cancer: the role of attitude toward uncertainty. Psychol Health 2002;17: 761-772.

25 National Genetic Information Centre (Erfocentrum): Voordat $\mathrm{u}$ aan kinderen denkt ... Informatie over erfelijkheidsvoorlichting (Before thinking about having children ... genetic counseling). Soestdijk, Vereniging Samenwerkende Ouder- en Patiëntenorganisaties (VSOP) (Dutch Genetic Alliance, VSOP), 1994. vsop @ vsop.nl,http://www. vsop.nl.
26 Vereniging Samenwerkende Ouder- en Patiëntenorganisaties (VSOP) (Dutch Genetic Alliance, VSOP): Erfelijke bloedarmoede (Inherited hemoglobin disorder). Soestdijk, VSOP, 2001.vsop@vsop.nl; http:// www.vsop.nl.

27 Steggles AN: Psychological aspects of genetic testing for cancer; unpublished thesis, University of London, London, 2001.

28 Yumuk PF, Gumus M, Ekenel M, Basaran G, Aliustaoglu M, Topal A, Turhal NS: Attitude toward genetic testing for cancer risk in Istanbul. Genet Test 2004;8:169-173.

29 Giordano PC, Dihal AA, Harteveld CL: Estimating the attitude of immigrants toward primary prevention of the hemoglobinopathies. Prenat Diagn 2005;25:885-893.

30 Ajzen I: Attitudes, Personality and Behavior. Milton Keynes, Open University Press, 1988.

31 Stichting Erfocentrum (National Genetic Information Centre), GG \& GD (Municipal Mental Health Centre) Amsterdam. 2005. http://www.erfelijkheid.nl/migranten/ voorlichtingsbijeenkomsten, info@sikkelcel. nl.

32 Stichting Erfocentrum (National Genetic Information Centre), Erasmus Medical Centre Rotterdam. 2006. http://www.zwangerwijzer.nl. 